\title{
Increase in the Energy Efficiency of Facilities by Using RES Systems as a Criterion for Environmental Quality Improvement
}

\author{
Sławomir Sowa ${ }^{1}$ \\ 1 Faculty of Environmental Engineering and Energy, Electrical Power Engineering Institute, Poznan University \\ of Technology, ul. Piotrowo 5, 60-965 Poznań, Poland \\ * Corresponding author's e-mail: Slawomir@sowa.poznan.pl
}

\begin{abstract}
Energy efficiency is directly linked to electricity and heat consumption. The amount of consumed energy has an obvious influence on the consumption of natural resources, the extraction and use of which for energy production has an impact on the environment. Implementation of the measures aimed at improving the energy efficiency of facilities, by reducing the electricity and heat consumption, translates into greater care for the environment. The article discusses the legal conditions and possible ways to improve the energy efficiency of facilities. It also presents the beneficial impact of reducing the final energy consumption on the environment. The analysis of the energy efficiency improvements made concerns public utilities as well as residential buildings, which constitute a highly energy-intensive sector. The article also discusses the advantages and validity of using the RES systems in construction to improve the energy efficiency of the facilities. The analysis based on the RES installations showed a reduction of the harmful compounds emission to the environment by increasing the energy efficiency of the facilities. Such a process is possible because the limitations in the final energy consumption have a direct impact on reducing the emissions of, among others, carbon dioxide into the atmosphere and the reduction of consumption of the fossil fuel resources. The measures aimed at improving the energy efficiency of facilities are regulated by national and international laws, directives and regulations. Environmental protection is also enforced by various legal regulations, issued by states and organizations. As inhabitants of the Earth, we should not wait for proper orders and prohibitions, but we should take care of our planet's future as well as limit its exploitation and poisoning.
\end{abstract}

Keywords: energy efficiency, environmental protection, RES, energy saving.

\section{INTRODUCTION}

The environmental protection measures can be implemented in many ways. The reduction of air pollution and the extraction of natural resources in the form of fossil fuels are the measures that significantly improve the environmental quality. The emission of carbon dioxide $\mathrm{CO}_{2}$ is the cause of the greenhouse effect that affects the climate and is responsible for its changes. The extraction of fossil fuels to produce electricity and heat is used practically from the very beginning of energy production. However, over the centuries and, years, the scale of energy generation and - as a consequence - the amount of energy used to produce it, have changed. Over the last 30 years, the global electricity consumption has increased by more than $250 \%$, from 10,901 TWh in 1990 to 23,690 TWh in 2018 [IEA 2019]. Such a significant increase in energy demand results in an increased consumption of fossil fuels. In Poland, electricity, and heat is generated mainly in conventional power plants, which means that the production of electricity and heat is carried out in the process of burning fossil fuels such as bituminous coal, lignite and natural gas. As a result, significant amounts of harmful gases and particulates are emitted into the atmosphere. An advantageous phenomenon is the increased share of renewable sources in energy production. In 2018, about 5,768.2 TWh of energy was produced worldwide from renewable energy sources (Hydro, Wind, Solar PV). Despite the growing share of RES in the global 
energy production, fossil fuels continue to cover the growing demand for energy. Increased energy consumption is not only due to economic growth but also to the climate change. The rise of the average temperature on Earth has resulted in higher demand for cooling, which is confirmed by the fact that the amount of energy consumed by the air conditioning systems is increasing. The best course of action is to implement the solutions that reduce the energy and heat consumption by facilities, i.e. improve their energy efficiency. This will reduce the operating costs and have a significant influence on improving the environmental quality.

\section{ENERGY EFFICIENCY OF FACILITIES}

The energy efficiency of facilities is identified with several factors that can be implemented at each stage of the facility's operation. The factors that determine the improvement of the energy efficiency of a facility are all kinds of measures aimed at reducing the consumption of the energy resources needed for the proper functioning of people or organizations that use the facility. We The implementation of renewable energy systems can also be considered as an improvement in the energy efficiency of a facility. The RES systems are the systems that generate electricity and heat from renewable energy sources. Although a facility may have the same energy demand as before the use of RES systems, these installations will consume less conventional energy. The facilities with the installations that cover the entire electricity and heat demand are referred to as Nearly Zero Energy Buildings (NZEB). At this level of energy efficiency, the facility does not need any external energy to function properly. At the same time, it practically does not emit any hazardous substances. The total demand for electricity and heat is supplied from the systems that use free solar, wind, water, and ground energy.

\section{TECHNICAL ASPECTS OF ENERGY EFFECTIVENESS}

The reduction of energy and heat consumption in the facility can be achieved through different measures. Among the actions that reduce heat consumption, we can include the execution of thermal insulation or replacement of the window and door joinery as well as elimination of all thermal bridges with which heat escapes from the facility. Energy savings can be achieved by using energy-efficient receivers, including light sources such as LED bulbs. These are the easiest and fastest ways to reduce the energy consumption. If such actions are combined with the installation of renewable energy systems, it can lead to a situation where the facility is completely independent from the energy supply of electricity and heat, produced conventionally. In terms of the electricity consumption savings, the control systems for electric devices such as lighting can be used [Sowa 2019]. By using the daylight to illuminate the rooms, the electricity consumption can be reduced by nearly $50 \%$. Improving the energy efficiency of lighting installations will support the use of daylight is a very costeffective, but unfortunately rarely used method of introducing savings in the electricity consumption [Sowa 2018].

\section{LEGAL ASPECTS}

The implementation of the measures aimed at improving the energy efficiency of the facilities is not only due to the pro-ecological attitude of the facility owners. The legal regulations, whether global, EU, or national, require the action to reduce the final energy consumption of facilities. One of such regulations is EU Directive 2012/27/EU [ESD 2012]. It imposes an obligation on Member States to take the measures to reduce final energy consumption by $1.5 \%$ per year. The Polish legislation includes the Act on Energy Efficiency of Facilities [UEE 2016]. It contains the definitions and legal regulations aimed at implementing the EU regulations on energy efficiency. The act also regulates the rules of implementing the obligation to achieve energy savings and conducting an energy audit of the enterprise. Another document implementing the provisions of the EU directives is the National Action Plan for Energy Efficiency [KPEE 2017]. The document states that in Poland in 2020, the primary energy consumption should be reduced by 13.6 Mtoe or 569.4 PJ. This is also the national energy efficiency target for 2020 . 


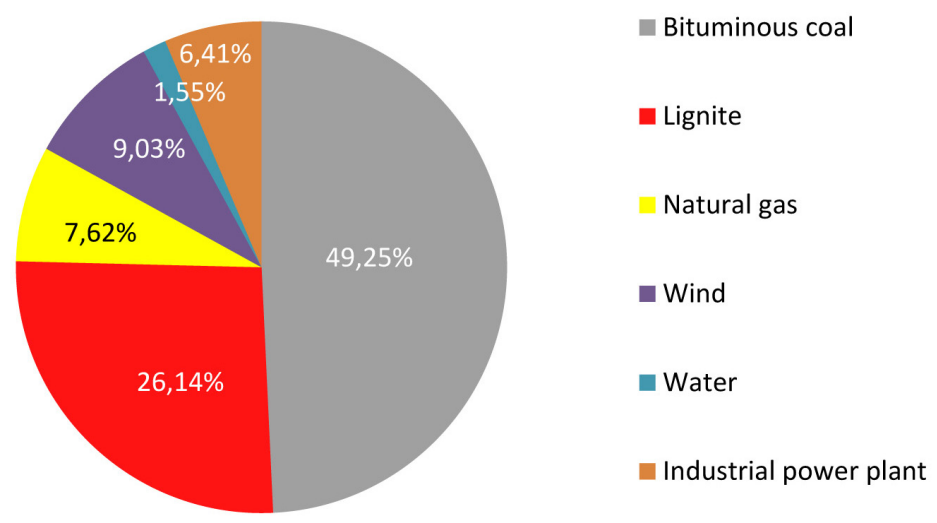

Figure 1. Power generated in the Polish power plants in 2019 by type of fuel [PSE 2020]

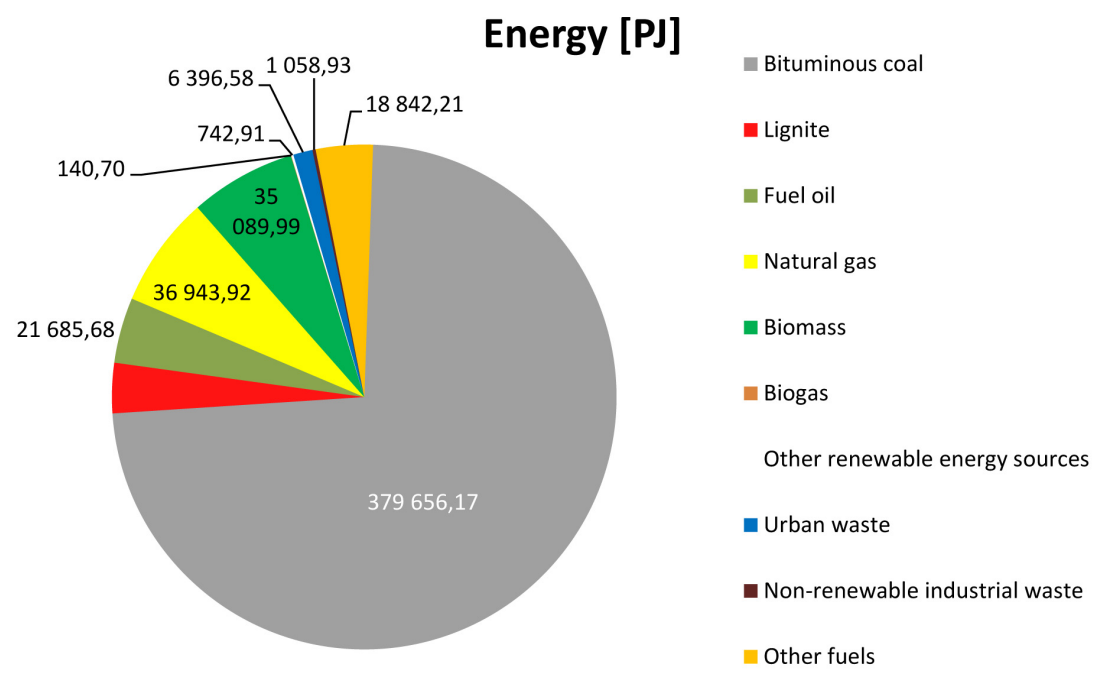

Figure 2. Heat energy generated in Polish heat and power plants in 2019 divided by the type of used fuel [PSE 2020]

\section{THE ENVIRONMENTAL ASPECT OF ELECTRICITY AND HEAT GENERATION}

In Poland, $75.39 \%$ of electricity is generated in conventional utility power plants, which are mainly based on bituminous coal and lignite [PSE 2020]. Renewable energy sources (wind, water, and other power plants) generate about $10.58 \%$ of total electricity generation in Poland. The structure of electricity generation in 2019 by the Polish power plants by fuel type is shown in Figure 1.

In the process of generating system heat in heating plants and combined heat and power plants, bituminous coal and lignite is also the dominant fuel. The second fuel, after bituminous coal, which has a significant share in the generation of heat, is natural gas. Slightly less heat is produced by biogas plants, which are classified as renewable energy systems. The structure of the heat produced, with a breakdown by the type of fuel used to produce it, is shown in Figure 2. The values given are expressed in PJ and have been recalculated for each fuel respectively.

In 2018, the fuel combustion installations producing electricity or electricity and heat emitted (about the emissions per electricity

Table 1. Emissions of harmful substances by the Polish power plants or CHPs in 2018 [KOBiZE 2019]

\begin{tabular}{|c|c|}
\hline Type of substance & Quantity [Gg] \\
\hline Carbon dioxide $\mathrm{CO}_{2}$ & 119899.867 \\
\hline Sulphur dioxide $\mathrm{SO}_{2}$ & 106.667 \\
\hline Nitrogen oxides $\mathrm{NO}_{x}$ & 98.849 \\
\hline Carbon monoxide CO & 43.152 \\
\hline Total dust & 5.618 \\
\hline Total & 120154.153 \\
\hline
\end{tabular}




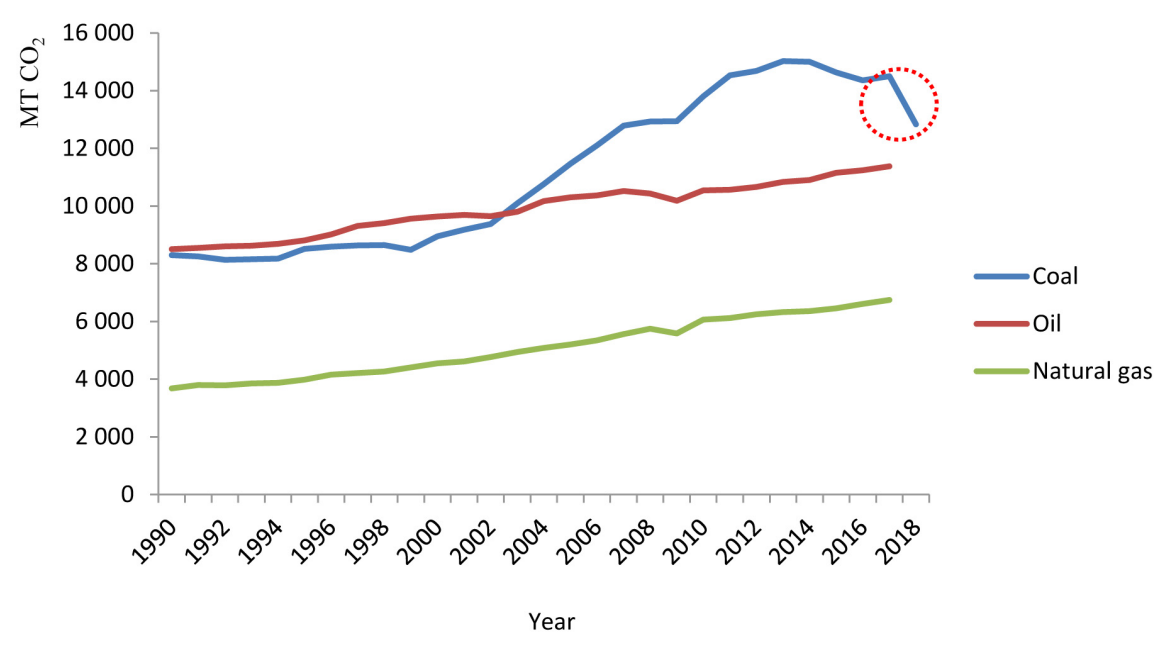

Figure 3. $\mathrm{CO}_{2}$ emissions caused by fuel combustion [IEA 2019]

production) nearly $120 \mathrm{Tg}$ of $\mathrm{CO}_{2}$ [KOBiZE 2019]. Detailed data concerning the emission of harmful substances by power plants or combined heat and power plants in 2018 are presented in Table 1.

The values of hazardous substances emitted shown in the above table are extremely high and significant for the environment. They affect climate change and degrade the environment.

Despite the efforts of national governments, society, and international organizations, global $\mathrm{CO}_{2}$ emissions are still increasing. The amount of $\mathrm{CO}_{2}$ emitted in the world between 1996 and 2017 is shown in Figure 3. The chart shows the coal combustion is most responsible for the emission of harmful $\mathrm{CO}_{2}$. The conclusion is that it is necessary to take the measures to reduce the emission of pollutants as soon as possible. Such an effect will occur as a result of reducing the heat and energy consumption in facilities. One of the effective ways is to improve the energy efficiency of facilities. Such measures include increasingly replacing fossil fuels with renewable energy sources. The RES installations used in buildings which were mentioned earlier can contribute to reducing the fossil fuel consumption and the emissions of harmful substances emitted during the production of electricity and heat.

Photovoltaic systems are another type of RES installations that have a positive influence on the environment. The installation of photovoltaic panels in Poland has become very popular. High willingness to install the PV systems by investors results, among others, from the local and government subsidies and favorable credit programs supporting the development of this branch of
RES. In Poland, at the end of 2019, there were over 155 thousand PV micro installations with a total installed capacity of nearly $1 \mathrm{GW}$. In total, all prosumers in 2019 introduced 324, 333 GWh of electricity into the network.

\section{RESULTS AND DISCUSSION}

The article presents how renewable energy sources installation reduces the demand for electricity and heat supply from other, external sources. The reduction in the consumption of electricity and heat in the facility, which has been produced in conventional energy sources, obviously has an influence on reducing the environmental pollution. The best possible way to achieve it is to equip a facility with RES installations, which will fully cover the energetical demand of the facility, so-called zero-energy facilities. Thus, the facility will not emit and contribute to the carbon dioxide emissions. The use of the above-mentioned solar installations, which are used to generate domestic hot water, can reduce the $\mathrm{CO}_{2}$ emissions at the level of $230 \mathrm{~kg}$ per year from $1 \mathrm{~m}^{2}$ absorber. Despite widespread opinions, this type of installation seems to be very popular among investors. This is mainly due to co-financing programs for the purchase and installation of solar collectors, i.e. Prosument 2 and Clean Air. In 2016 in Poland, all solar collector installations generated energy equal to $1791 \mathrm{MWh}$. [Solar Thermal 2019]. This means that the operating solar installations reduced the $\mathrm{CO}_{2}$ emission by 1,418 tons per year.

The year 2019 was a record-breaking year in terms of the number of PV micro installations 
launched and the amount of electricity fed into the grid by prosumers. If it is assumed that the emission factors for the electricity produced in fuel combustion installations are 792 [kg/MWh] for carbon dioxide $\left(\mathrm{CO}_{2}\right)$, then a $10 \mathrm{~kW}$ PV installation, which generates about $10 \mathrm{MWh}$ of energy per year, can reduce the $\mathrm{CO}_{2}$ emissions by $7920 \mathrm{~kg}$ per year. All micro PV installations in Poland introduced more than $324 \mathrm{GWh}$ of electricity into the network in 2019. This means that the $\mathrm{CO}_{2}$ emission was reduced by 256.9 tons. If it is assumed that the amount of the energy generated by the collectors in 2019 remains unchanged, then when counting the emission reduction values from the solar and photovoltaic collector installations, a total value of 1674.9 tons per year is obtained. This value was shown in the last period of the curve representing the $\mathrm{CO}_{2}$ emissions during coal combustion and marked with a red dotted circle. In Poland, coal is the main fuel from which electricity and heat are produced; therefore, this curve shows to what extent the share of renewable energy systems affects the reduction of the $\mathrm{CO}_{2}$ emissions.

In recent years, heat pumps, both those that draw the heat from the ground and the air, have become increasingly popular. Estimating the number of installed heat pump systems is only possible based on the sales reports from leading manufacturers of these systems for heating facilities. The power of a heat pump depends on many installation conditions related to the type of facility, its use, and location. It can be assumed that a $13 \mathrm{~kW}$ air heat pump can cover the heat demand in a $350 \mathrm{~m}^{2}$ facility.

In order to illustrate the beneficial impact of renewable energy systems on the environment more clearly, Figure 4 shows the values of emissions of harmful compounds into the atmosphere by coal-fired power plants and the quantities that are not emitted due to the appropriate renewable energy systems. According to estimations, the heat pumps installed in Poland in 2020 will produce a total of $260 \mathrm{kToe} / \mathrm{year}$ [PC]. Heat pump installations are another example of RES systems that improve the efficiency of facilities by reducing the consumption of heat generated conventionally or supplied by an external operator.

The article presents the popular RES systems the number and size of which is monitored by the Polish energy system. However, it should be noted that apart from solar collectors, photovoltaic installations, and heat pumps, there are also wind turbines and small hydropower plants. The installation of wind turbines is beneficial only at specific locations with appropriate wind conditions. Due to the procedural formalities, these installations are not often found in residential or public facilities. Another important aspect is the noise generated by the turbine and the relatively weak ratio of performance to the purchase and installation price of the wind power system. However, in the areas with lower development density and located under favorable wind conditions, e.g. at the seaside or in the mountains, such installations are installed. In 2019, the total installed capacity of micro wind power installations was 385 kW. Small hydropower plants are much more efficient. For their installation, it is necessary to have an appropriate location and terrain. In 2019 , the installed capacity of micro-hydroelectric installations in Poland was 8.258 MW.

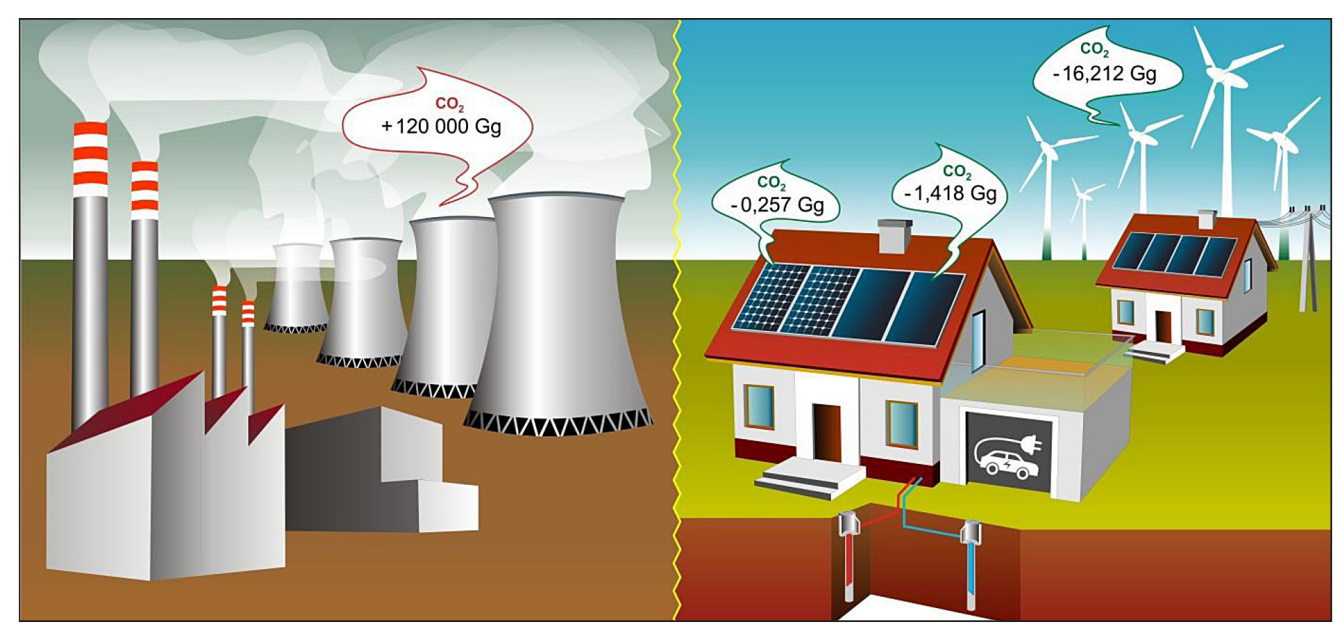

Figure 4. The values of emissions of harmful compounds into the atmosphere by coal-fired power plants and the quantities that are not emitted due to appropriate renewable energy systems 


\section{CONCLUSION}

Increasing demand for electricity and heat results in higher consumption of the natural resources necessary to produce the required energy and heat. Increased energy production results in higher emissions of hazardous substances into the atmosphere. The legal regulations that are being introduced require the measures to reduce the energy and heat consumption. At the same time, the government programs that support the activities and technologies aimed at increasing the energy efficiency of facilities are being implemented. One of such programs is the governmental program 'Clean Air', the implementation of which allowed to reduce the $\mathrm{CO}_{2}$ emission by $6 \%$ [Zyśk et al.]. In Figure 3, the section marked with a red circle in the diagram shows a decrease in the $\mathrm{CO}_{2}$ emissions due to the use of solar collectors and PV micro installations. The visible reduction of $\mathrm{CO}_{2}$ clearly shows the significance of the installations which improve the energy efficiency of the building and at the same time have a positive influence on the environment.

\section{REFERENCES}

1. KOBiZE 2019. Krajowy Ośrodek Bilansowania i Zarządzania Emisjami. Wskaźniki emisyjności $\mathrm{CO}_{2}, \mathrm{SO}_{2}, \mathrm{NOx}, \mathrm{CO}$ i pyłu całkowitego dla energii elektrycznej. Warszawa 2019.
2. IEA 2019. Global Energy \& $\mathrm{CO}_{2}$ Status Report 2019. International Energy Agency. Paris 2020.

3. DUE 2012. Directive 2012/27/EU of the European Parliament and of the Council of 25 October 2012 on energy efficiency. Brussels 2012.

4. KPEE 2017. Krajowy Plan Działań dotyczący efektywności energetycznej dla Polski 2017. Ministerstwo Energii, Departament Elektroenergetyki i Ciepłownictwa Warszawa 7.06.2018 r.

5. PSE 2020. Raport KSE: Zestawienie danych ilościowych dotyczących funkcjonowania KSE w 2019 roku.

6. Solar Thermal 2019. Solar Thermal and Concentrated Solar Power Barometers. Eurobserver - June 2019.

7. Sowa 2018. Sowa S. 2018. Improving the energy efficiency of lighting systems by the use of solar radiation. E3S Web of Conferences, 70, 01013.

8. Sowa 2019. Sowa S. 2019. Lighting control systems using daylight to optimise energy efficiency of the building. Progress in Applied Electrical Engineering, 1-4.

9. URE 2019. Raport URE: Energetyka cieplna w liczbach -2018.

10. Zyśk 2019. Zyśk J., Olkuski T., Kogut K., Adam A., Surówka M. 2019. Assessment of the impact of the implementation of air protection programs, antismog resolutions and the "Clean Air" program on $\mathrm{CO}_{2}$ emission. Energy Policy Journal, 22(2), 133-154.

11. Żukowski 2016. Żukowski M. 2016. Ocena efektu ekologicznego wynikającego z zastosowania kolektorów słonecznych. Annual Set The Environment Protection, 18, 284-293. 